\title{
PAGI SAMPAI MALAM HARI: REPRESENTASI LATAR WAKTU DALAM CERITA ANAK INDONESIA
}

\author{
Seni Apriliya, Hodidjah, dan Umul Kholifah \\ Universitas Pendidikan Indonesia \\ Email: seni_apriliya@upi.edu,
}

\begin{abstract}
(Title: From Morning to Night: Representation of Time Settings in Indonesian Children's Stories). This paper aims to describe the time setting of children's stories. The study uses content analysis methods with categorization, tabulation, and inference techniques. Research data sources are 10 children's stories compiled in a book entitled "Naskah Terbaik Lomba Menulis Cerita Anak Tahun 2015 (Best Manuscripts of Children's Story Writing Competition)". The book was chosen purposively because it represented the work of Indonesian children who won national writing competitions. The results showed that (1) the time setting in children's stories was dominated by certain times of the day, such as morning, afternoon, evening, and night; (2) there are several time settings based on month/season/year, time settings based on a person's life phase, time settings based on specific history/events, time settings that indicate the past, present, and future; and (3) found a very specific time setting: referring to certain hours, and referring to the position of the sun. Thus, the time setting in the story is represented in various forms. This shows the creativity of Indonesian children in their work.
\end{abstract}

Keywords: children's stories, intrinsic elements, time setting.

\section{PENDAHULUAN}

Telah banyak kajian yang menunjukkan bahwa sastra -anak- memiliki potensi luar biasa dalam mengawal tumbuh kembang anak. Sastra dipandang sangat powerful, karena dapat mencerminkan kehidupan sebagaimana adanya dan memungkinkan anak-anak yang menjadikan para pembacanya dapat memahami dunia (Strehle, 1999). Dan dengan pemahaman tersebut mereka dapat terhubung -melihat, memahami, untuk kemudian terlibat- dengan dunianya.

Latar merupakan salah satu unsur "dunia" yang menjadi landas tumpu dibangun dan terbangunnya sebuah cerita. Melalui latar -waktu, tempat, dan suasana-, sebuah peristiwa diletakkan sebagai struktur cerita secara masuk akal dan berterima. Sayangnya, kajian tentang latar dalam cerita anak masih terbatas jumlahnya, apalagi kajian yang difokuskan pada latar waktu. Bahkan, pada karya berupa dongeng, atau fairy tale justru terkenal dengan penggunaan latar yang timeless dan spaceless (Thomas, 1986); tak ayal frasa pada suatu waktu/once upon a time menjadi sedemikian familiar sebagai representasi latar dalam ceritanya.

Sejumlah kajian tentang latar lebih difokuskan pada latar tempat. Di antaranya kajian tentang hutan, kastil, menara, dan gubuk sebagai latar tempat yang banyak digunakan pada fairy tale (Thomas, 1986). Kajian lainnya difokuskan pada latar tempat di suatu wilayah geografis tertentu, yakni cerita dengan latar Spanyol tepatnya di wilayah Andalusia, sebuah segitiga tertutup antara Granada, Linares dan Cordoba, dibatasi di utara oleh sungai Guadalquivir (Hansen, 1968); cerita dengan latar kawasan Eropa abad pertengahan (Swandayani, Santoso, \& Nurhayati, 2013).

Dalam konteks sastra Indonesia, meskipun tidak spesifik pada sastra anak, terdapat kajian ihwal beberapa kota di wilayah DIY, Jawa Tengah dan Jawa Timur yang dominan menjadi latar cerita dan nama hari berdasarkan penanggalan Jawa sebagai latar waktu pada novel Indonesia 1980-1995 (Hartono, 2015); sertakajiantentanglingkungan hidup -hutan, tanah, air, terutama pohon- yang diposisikan sebagai latar tempat dan waktu 
pada karya sastra kontemporer (Dewi, 2015). Selain itu, terdapat kajian tentang latar waktu yang pembahasannya lebih difokuskan pada bagaimana latar waktu tertentu menjadipenanda tindak korupsi berikut karakteristiknya (Anwar, 2012). Berbeda dengan kajian tersebut, tulisan ini difokuskan pada bagaimana representasi latar waktu dalam cerita anak Indonesia.

Latar merupakan salah satu unsur intrinsik yang perlukan untuk membangun, memperkuat, dan menghidupkan jalannya sebuah cerita. Sebagaimana pendapat Tarigan (1985) latarlah yang menjadi landas tumpu cerita. Latar suatu cerita dapat mempunyai suatu relasi yang lebih langsung dengan arti keseluruhan dan arti yang umum dari sesuatu cerita (Abrams dalam Nurgiyantoto, 2013). Latar dibedakan menjadi latar tempat, waktu, dan sosial (Munaris, 2011; Kusmarwanti, 2010). Namun, dengan mempertimbangkan keluasan dan kedalaman kajian, tulisan ini hanya membahas latar waktu, guna menjawab pertanyaan apakah dalam cerita anak Indonesia terdapat latar waktu tertentu atau timeless sebagaimana banyak ditemui pada sastra anak jenis fairy tale (Thomas, 1986)? Apabila dalam cerita anak Indonesia ditemukan penggunaan latar waktu, latar waktu apa saja yang direpresentasikan?

Karya sastra memiliki kemampuan potensial untuk mengajari anak-anak tentang cara melihat dunia (Strehle, 1999), dalam konteks tulisan inikhususnya, dalam hal konteks waktu. Sebagaimana halnya latar tempat dalam cerita yang dapat berperan signifikan dalam menambah wawasan pembaca (Swandayani et al., 2013). Selain itu, kajian tentang latar dalam cerita anak penting dilakukan sekaitan dengan pembelajaran sastra di lingkungan pendidikan formal. Merujuk kurikulum SD, sesuai dengan Permendikbud Nomor 24 Tahun 2016, pembelajaran sastra mengenai latar cerita, terdapat di kelas V SD, yaitu pada Kompetensi Dasar (KD) 4.8, "Menyajikan kembali peristiwa atau tindakan dengan memperhatikan latar cerita yang terdapat pada teks fiksi."

Dengan demikian, hasil kajian tentang latar dalam cerita anak Indonesia akan berguna sebagai bahan ajar sastra pada materi terkait di SD. Dalam pemilihan bahan ajar apresiasi cerita latar dalam sebuah cerita perlu disesuikan dengan latar kehidupan anaka. Maka dari itu, sebelum melakukan apresiasi sastra, guru harus memastikan cerita tersebut layak digunakan untuk peserta didik. Latar penting diperhatikan agar dalam pemilihan cerita sesuai dengan pengetahuan siswa SD dan agar anak dapat dengan mudah memahami isi cerita tersebut. Karena jika latar dalam cerita sudah dikenal anak, khususnya latar waktu, hal itu akan semakin melibatkan anak ke dalam cerita sebab merasa seolah-olah dirinya berada dalam masa waktu terjadinya peristiwa dari cerita itu. Saat ini sudah banyak cerita yang dibuat oleh anakanak Indonesia usia SD. Dengan demikian, perlu diketahui bagaimana kualitas cerita yang dibuat oleh anak-anak tersebut, khususnya unsur latar waktu di dalamnya, apakah memiliki kesesuaian dengan kehidupan mereka seharihari atau tidak. Karena asumsinya, cerita yang mereka buat tentunya terispirasi dari ruang lingkup kehidupan dan lingkungan di sekitar mereka. Buku yang memuat kumpulan cerita karya anak-anak Indonesia usia SD tersebut, salah satunya adalah Naskah Terbaik Lomba Menulis Cerita Anak (LMCA).

LMCA merupakan ajang lomba menulis cerita tingkat nasional yang sasaran peserta lombanya anak-anak siswa SD/sederajat dari seluruh wilayah Indonesia. Perlombaan tersebut merupakan salah satu program yang diselengarakan oleh Direktorat Jendral Pendidikan Dasar dan Menengah sejak tahun 2011. Adapun tujuannya untuk menigkatkan dan memotivasi tumbuh kembang budaya literasi di kalangan anak usia SD. Cerita hasil karya para pemenang lomba terhimpun dalam buku NT LMCA. Karya cerita tersebut dibuat oleh anak-anak yang berasal dari seluruh Indonesia sehingga merepresentasikan anak Indonesia.

\section{METODE}

Penelitian difokuskan untuk menggambarkan latar waktu dalam cerita anak Indonesia. Sejalan dengan tujuan tersebut digunakan pendekatan kualitatifdengan metode analisis konten. Data yang dikumpulkan adalah data verbal, terdiri atas kutipan kata-kata, frasa, paragraf, atau wacana (Given, 2008; Moleong, 
2006). Pengumpulan data dilakukan dengan teknik membaca berulang dan mencatat data berdasarkan rumusan masalah, yaitu latar waktu. Adapun pengolahan data dilakukan melalui kategorisasi dan tabulasi sesuai dengan kelompok data tertentu; kemudian data tersebut dianalisis dan diinterpretasi sesuai dengan teori latar waktu menurut Nurgiyantoro (2002) dan Marqua $\beta$ (1997) sampai diperoleh inferensi.
Objek material penelitian ini adalah 10 cerita anak Indonesia (lihat Tabel 1) yang terhimpun dalam buku Naskah Terbaik Lomba Menulis Cerita Anak (NT LMCA) Tahun 2015 yang diterbitkan oleh Kementrian Pendidikan dan Kebudayaan Indonesia. Objek formal penelitian ini adalah unsur latar waktu dalam cerita anak Indonesia tersebut. Instrumen yang digunakan untuk mengumpulkan data dalam penelitian ini berupa kartu data.

Tabel 1. Judul Cerita dan Pengarang Naskah Terbaik LMCA Tahun 2015

\begin{tabular}{cll}
\hline No. & \multicolumn{1}{c}{ Judul Cerita } & \multicolumn{1}{c}{ Pengarang } \\
\hline 1 & Mencari Ujung Pelangi & Kalyana Adzhara \\
2 & Harga Sebuah Kejujuran & Bintang Nurul Hidayati \\
3 & Mukena untuk Ibu & Gita Mawadah Yulianna \\
4 & Seorang Ibu dari Warung Kecil & Shofiyyah Lukman \\
5 & Sahabat dari Senja & Pandan Raditya Arundhati Satya \\
6 & Putri Salju dan Satu Kurcaci & Khansa Tabina Khairunissa \\
7 & Motor Butut Kesayangan Eyang & Aflahonintya Azka Ardhana \\
8 & Moni yang Malang & Reyfasha Zahara Suharmoko \\
9 & Belajar di Candi Jago & Al Uyuna Galuh Cantika \\
10 & Kue Pukis untuk Nenek & Princeyla Aughea \\
\hline
\end{tabular}

\section{Hasil dan Pembahasan}

Berdasarkan analisis data yang dilakukan terhadap 10 cerita anak Indonesia, ditemukan adanya latar waktu pada setiap cerita. Selaras dengan gagasan Nurgiyantoro (2013) latar waktu tersebut berkaitan dengan "kapan" terjadinya peristiwa-peristiwa yang ada dalam cerita. Di dalam setiap cerita, terdapat lebih dari satu pengunaan latar waktu. Penggunaan latar waktu yang paling banyak terdapat pada cerita MBKE, yaitu sebelas bentuk latar waktu. Sedangkan yang paling sedikit terdapat pada cerita BDCJ, yaitu dua bentuk latar waktu. Latar waktu pada cerita anak Indonesia secara lengkap disajikan pada Tabel 2. 
Tabel 2. Latar Waktu dalam Naskah Terbaik LMCA Tahun 2015

\begin{tabular}{|c|c|c|c|c|c|c|c|c|c|c|c|}
\hline \multirow{3}{*}{ No. } & \multirow{3}{*}{$\begin{array}{l}\text { Indikator Latar } \\
\text { Waktu }\end{array}$} & \multicolumn{10}{|c|}{ CERITA KE- } \\
\hline & & 1 & 2 & 3 & 4 & 5 & 6 & 7 & 8 & 9 & 10 \\
\hline & & MUP & HSK & MUI & SIDWK & SDS & PSDSK & MBKE & MYM & BDCJ & KPUN \\
\hline 1 & $\begin{array}{l}\text { Waktu tertentu } \\
\text { dalam satu } \\
\text { hari }\end{array}$ & Pagi & Pagi & $\begin{array}{l}\text { Malam, } \\
\text { siang }\end{array}$ & Pagi, sore & $\begin{array}{l}\text { Sore, } \\
\text { malam, } \\
\text { pagi, } \\
\text { senja. }\end{array}$ & Pagi & $\begin{array}{l}\text { siang, } \\
\text { pagi, } \\
\text { sore, } \\
\text { malam. }\end{array}$ & $\begin{array}{l}\text { Sore, } \\
\text { pagi, dan } \\
\text { malam }\end{array}$ & - & - \\
\hline 2 & $\begin{array}{l}\text { Waktu } \\
\text { berdasarkan } \\
\text { bulan/musim/ } \\
\text { tahun }\end{array}$ & - & - & $\begin{array}{l}\text { bulan } \\
\text { ramadhan, } \\
\text { dan hari } \\
\text { raya }\end{array}$ & - & - & - & - & - & - & - \\
\hline 3 & $\begin{array}{l}\text { Waktu } \\
\text { berdasarkan } \\
\text { fase kehidupan } \\
\text { seseorang }\end{array}$ & saat kecil & - & - & - & - & - & - & - & - & $\begin{array}{l}\text { masa } \\
\text { kecil }\end{array}$ \\
\hline 4 & $\begin{array}{l}\text { Waktu } \\
\text { berdasarkan } \\
\text { sejarah/ } \\
\text { peristiwa } \\
\text { tertentu }\end{array}$ & - & - & - & - & $\begin{array}{l}\text { Hari } \\
\text { Anak } \\
\text { Nasional }\end{array}$ & - & - & - & - & - \\
\hline 5 & $\begin{array}{l}\text { Waktu yang } \\
\text { menunjukkan } \\
\text { masa lampau }\end{array}$ & $\begin{array}{l}\text { Suatu } \\
\text { hari, dua } \\
\text { tahun } \\
\text { yang lalu }\end{array}$ & $\begin{array}{l}\text { Tiga } \\
\text { bulan } \\
\text { yang } \\
\text { lalu, } \\
\text { sejak } \\
\text { dulu }\end{array}$ & - & kemarin & $\begin{array}{l}\text { suatu } \\
\text { hari, } \\
\text { seminggu } \\
\text { berlalu }\end{array}$ & $\begin{array}{l}5 \text { bulan } \\
\text { lalu }\end{array}$ & $\begin{array}{l}\text { Sudah } \\
\text { dua tahun }\end{array}$ & suatu hari & - & $\begin{array}{l}20 \\
\text { tahun } \\
\text { lalu }\end{array}$ \\
\hline 6 & $\begin{array}{l}\text { Waktu yang } \\
\text { menunjukkan } \\
\text { masa kini }\end{array}$ & Sekarang & - & - & - & - & - & $\begin{array}{l}\text { setiap } \\
\text { hari, hari } \\
\text { ini }\end{array}$ & - & - & - \\
\hline 7 & $\begin{array}{l}\text { Waktu yang } \\
\text { menunjukkan } \\
\text { masa yang } \\
\text { akan datang }\end{array}$ & $\begin{array}{l}\text { beberapa } \\
\text { hari } \\
\text { kemudian }\end{array}$ & $\begin{array}{l}\text { dua } \\
\text { minggu } \\
\text { lagi }\end{array}$ & $\begin{array}{l}\text { Besok, } \\
\text { esok } \\
\text { harinya, } \\
\text { dua hari } \\
\text { lagi }\end{array}$ & besok & - & $\begin{array}{l}\text { keesokan } \\
\text { harinya }\end{array}$ & $\begin{array}{l}\text { besok, } \\
\text { satu } \\
\text { minggu, } \\
\text { keesokan } \\
\text { harinya }\end{array}$ & $\begin{array}{l}\text { keesokan } \\
\text { hari }\end{array}$ & - & Besok \\
\hline 8 & $\begin{array}{l}\text { Latar waktu } \\
\text { yang sangat } \\
\text { spesifik }\end{array}$ & - & - & - & $\begin{array}{l}\text { pukul, } \\
\text { matahari } \\
\text { terbit }\end{array}$ & - & - & Pukul & - & $\begin{array}{l}\text { Hari } \\
\text { Sabtu } \\
\text { tanggal } \\
29 \\
\text { Agustus } \\
2015 . \\
\text { Dan hari } \\
\text { semakin } \\
\text { gelap. }\end{array}$ & - \\
\hline
\end{tabular}

Latar waktu pada cerita diklasifikasi berdasarkan kategori masa lampau, masa kini, masa yang akan datang, suatu waktu tertentu dalam satu hari, suatu waktu tertentu dalam setahun, suatu waktu tertentu dalam fase kehidupan seorang tokoh, dan suatu waktu tertentu yang memiliki latar belakang sejarah.

1) Masa lampau, yang menunjukkan waktu yang telah lewat. Terdapat 7 dari 10 cerita yang menggunakan latar waktu masa lampau sebagaimana tampak pada kutipan "Sudah dua tahun yang lalu ketika aku dan Ferdi mencari ujung pelangi." (2015. MUP.9); Wulan ingat benar, betapa sedih dan bingung keluarganya, tiga bulan yang lalu. (2015.HSK.20); Shila mengamati orang yang berhutang kemarin menuju toko di depan warungnya. (2015.SIDWK.62); Seminggu berlalu. Saat yang kutunggu telah datang. (2015.SDS.78); Mbak Lili sudah bekerja di rumah ini sejak 5 bulan yang lalu. (2015.PSDSK.87); Sudah dua tahun ini Eyang kakung pensiun... (2015. MBKE.107); serta "Tanggal di foto itu, ternyata tepat 20 tahun yang lalu!'” (2015. KPUN.155).

2) Masa kini, yang menunjukkan waktu tengah berlangsungnya suatu peristiwa. Terdapat 2 dari 10 cerita yang menggunakan latar waktu masa kini, sebagaimana tampak pada kutipan Sebaiknya kita berangkat sekarang, nanti keburu sore. (2015. MUP.6); dan Hari ini, Eyang mengajakku kembali jalan-jalan mengelilingi desa. (2015.MBKE.110).

3) Masa akan datang, menunjukkan waktu suatu peristiwa yang akan terjadi. Terdapat 8 dari 10 cerita yang menggunakan latar waktu tersebut; sebagaimana tampak pada kutipan Beberapa hari kemudian banjir surut menjadi semata kaki. (2015. MUP.10); "Anak-anak, dua minggu lagi akan diadakan lomba cerdas cermat... (2015.HSK.21); Lebaran tinggal dua 
hari lagi. (2015.MUI.46); “Uhh..., besok hari Minggu. (2015.SIDWK.61); "Kalau Nenek suka, besok Ayang beliin lagi ya!" (2015.KPUN.155); Keesokan harinya, aku berjalan menuju kelas...(2015.PSDSK.92); Hingga tak terasa aku terlelap sampai keesokan harinya. (2015.MBKE.117); serta Keesokan harinya Moni terbangun. (2015.MYM.129).

4) suatu waktu tertentu dalam satu hari, yang mengungkapkan keadaan tokoh dalam cerita. Terdapat 8 dari 10 cerita menggunakan waktu ini, seperti pagi, siang, sore atau malam. Latar waktu pagi sering digunakan dalam cerita. Berikut beberapa contoh kutipannya Di pagi hari itu, terjadi keributan besar. (2015.MUP.9); Pagi-pagi sekali, Wulan dan Niken sudah datang di sekolah. (2015.HSK.25); Pagi itu sangat dingin, Ibu menggigil sambil memegangi tangannya. (2015.SIDWK.57); Pagi yang cerah, matahari bersinar terang, cahayanya memasuki jendela kamarku. (2015.PSDSK.87); Suatu pagi, Pak Kasim, Mandor perkebunan kelapa sawit menemukan bangkai seekor orangutan Borneo remaja. (2015.MYM.131); Siangsiang sepulang sekolah begini, menikmati buah juwet adalah kegemaranku sejak kecil. (2015.MBKE.107); Cerita Pak Yitno, telah mempengaruhi sikapku terhadap suara misterius yang selalu menghantuiku setiap sore. (2015.SDS.74); Sahabat yang kutemui kala senja. (2015.SDS.80); dan Malam itu angin berhembus sangat kencang... (2015.MUI.41).

5) Suatu waktu tertentu dalam kurun setahun, yang mengungkapkan keadaan tokohnya. Terdapat dalam satu cerita sebagaimana tampak pada kutipan "Ohiya, ini kan musim hujan ...." (2015.MUI.44); Hari demi hari Ira lalui, sampai bulan Ramadhan pun datang. (2015.MUI.46); dan Hari raya pun tiba ... (2015.MUI.48)

6) Suatu waktu tertentu dalam fase kehidupan seorang tokoh dalam cerita. Terdapat 2 dari 10 cerita yang menggunakan latar waktu tersebut sebagaimana tampak pada kutipan "... lalu melihat sebuah foto Tante Ria waktu kecil." (2015.KPUN.155); serta

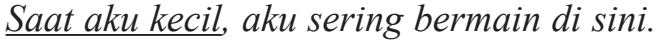
(2015.MUP.7).

7) Suatu waktu tertentu yang memiliki latar belakang sejarah: hari yang bersejarah, hari besar nasional, peristiwa sosial dan lain sebagainya. Terdapat dalam satu cerita yang termasuk latar waktu tersebut, yaitu peristiwa Hari Anak Nasional, seperti tampak pada kutipan “... mari di Hari Anak Nasional ini, kita selamatkan anak ini!" (2015.SDS.79).

8) Pada cerita anak Indonesia, ditemukan latar waktu yang tidak terakomodasi oleh ketujuh bentuk tersebut karena latar waktu yang digunakan sangat spesifik, yaitu merujuk pada jam tertentu, dan merujuk pada posisi keadaan matahari pada waktu tertentu. Oleh karena itu, tulisan ini menambahan latar waktu dengan kategori waktu spesifik, yang merujuk pada latar waktu yang dinyatakan secara presisi, jelas, dan lugas menunjukkan kapan tepatnya suatu peristiwa terjadi dalam cerita. Penggunaan latar waktu spesifik yang menunjukkan jam tertentu, ditunjukkan pada kutipan ... pukul 6 pagi, Ibu sudah selesai membersihkan rumah... (2015.SIDWK.57); "Biasanya kan, buka pukul 7?" (2015.SIDWK.57); Jam menunjukan pukul 08.15 ... (2015. MBKE.111). Selanjutnya, penggunaan latar waktu spesifik yang menunjukkan hari, tanggal, dan bulan, secara lengkap sebagaimana terdapat pada kutipan "Akhirnya mimpiku kesampaian ketika aku bersama keluargaku berkunjung pada hari Sabtu, tanggal 29 Agustus 2015. (2015.BDCJ.137). Terakhir, latar waktu spesifik yang menunjukkan posisi/ keadaan matahari, sebagaimana tampak pada kutipan Matahari terbit, langit mulai cerah. (2015.SIDWK.57).

Secara umum, latar waktu yang dominan muncul pada cerita anak Indonesia adalah suatu waktu tertentu dalam rentang satu hari, yaitu pagi, siang, sore, senja, dan malam. Hal ini terjadi disebabkan karena latar waktu tersebut secara konkret dialami anak dalam kehidupan sehari-hari (Nurgiyantoro, 2013:253) dan terjadi setiap hari sehingga sangat familiar dalam skema waktu harian 
anak-anak. Dengan demikian, penulis anak Indonesia dapat dengan mudah menggunakan waktu-waktu tersebut sebagai latar dalam cerita. Latar waktu tersebut tergolong waktu masa kini yang bersifat konkret dan fungsional. Dari perspektif pembaca, hal tersebut dapat menarik perhatian pembaca anak-anak karena akan memudahkan mereka dalam memahami cerita. Latar yang fungsional dan baik mampu membangkitkan mood, keaslian, kredibilitas sebuah cerita, dan akan mengesankan bagi anak-anak. Oleh karena itu, tak berlebihan kiranya apabila pemanfaatan sastra anak dapat lebih terbangun dalam mengembangkan imajinasi (Irawati \& Purwani, 2013).

Latar waktu spesifik menjadi temuan yang menarik, karena ternyata cerita anak Indonesia memiliki keragaman sekaligus keunikannya tersendiri dalam merepresentasikan latar waktu. Keragaman tersebut, membuktikan bahwa latar waktu pada cerita anak berbeda dengan fairy tale yang dikenal timeless (Thomas, 1986). Hal ini menunjukkan bahwa anak-anak Indonesia memiliki kesadaran waktu yang ditunjukkan melalui karya-karya mereka. Imajinasi dan daya kreasi dalam menyajikan latar cerita detail dan presisi, yang membuktikan bahwa para pengarang memang anak-anak berprestasi yang layak dan pantas dijadikan teladan sesamanya (Apriliya, 2017). Hadirnya karya sastra anak dengan konten latar waktu sedemikian kaya, menjadikan pertanyaan seorang pakar pendidikan (Rogers, 2009) ihwal apakah sastra membantu anak-anak lain untuk mengetahui dengan cara-cara baru, membaca dunia dengan cara-cara baru, dan menegosiasikan tanggapan mereka di dunia postmodern? tampaknya telah beroleh jawaban yang sepadan.

\section{SIMPULAN}

Berdasarkan pembahasan dapat disimpulkan bahwa terdapat latar waktu dalam cerita anak Indonesia yang direpresentasikan dalam beragam bentuk. Suatu waktu tertentu dalam sehari -pagi, siang, sore, senja, dan malammenjadi latar waktu yang paling dominan digunakan dalam cerita. Ditemukannya kategori latar waktu spesifik, yang merujuk pada latar waktu yang dinyatakan secara presisi, jelas, dan lugas menunjukkan kapan tepatnya suatu peristiwa terjadi dalam cerita, meliputi jam, titimangsa, dan posisi/keadaan matahari. Keberagaman latar waktu pada cerita menunjukkan kreativitas anak Indonesia dalam berkarya.

\section{UCAPAN TERIMA KASIH}

Artikel ini ditulis berdasarkan sebagian hasil Penelitian Kolaborasi Dosen dan Guru Sekolah Laboratorium Tahun 2019. Oleh karena itu, kami menyampaikan ucapan terima kasih kepada LPPM UPI yang telah memfasilitasi pembiayaan kegiatan penelitian melalui dana PNBP UPI. Terima kasih juga kepada guru di SD Laboratorium UPI Kampus Tasikmalaya atas kesediaan sebagai mitra dalam penelitian ini.

\section{DAFTAR PUSTAKA}

Anwar, M. S. (2012). Perkembangan Korupsi dalam Novel Indonesia. ATAVISME, 15(2), 133-146.

Apriliya, S. dkk. (2017). Profil Pengarang Anak Indonesia sebagai Role Model Pendidikan Karakter. Indonesian Journal of Primary Education. 1(2). 62-69

Adzahra, K., dkk. (2016). Mencari Ujung Pelangi, Naskah Terbaik Lomba Menulis Cerita Anak 2015. Jakarta: Kementrian Pendidikan dan Kebudayaan.

Badan Standar Nasional Pendidikan. (2006). Standar Isi Standar Kompetensi dan Kompetensi Dasar Kurikulum Tingkat Satuan Pendidikan Jenjang Sekolah Dasar. Jakarta: BSNP.

Dewi, N. (2015). Manusia dan Lingkungan dalam Cerpen Indonesia Kontemporer: Analisis Ekokritik Cerpen Pilihan Kompas. LITERA, 14(2), 376-391.

Given, L.M. 2008. The SAGE Encyclopedia of Qualitative Research and Method, 1 \& 2. Newyork: SAGE Publications.

Hansen, I. V. (1968). The Spanish setting: a reappraisal of. Children's Literature in Education, 186-191. 
Hartono. (2015). Warna Lokal dalam Novel Indonesia Periode 1980-1995. LITERA, 14(2), 392-403.

Irawati, R. P., \& Purwani, N. (2013). NilaiNilai Moralitas dan Budaya Asing dalam Sastra Anak Terjemahan Melalui Pemaknaan Sastra Anak oleh Anak. Lingua, IX(1), 46-53.

Kusmarwanti. (2010). Karakteristik Cerpencerpen Cyber. LITERA, 9(2), 190203.

Marquaß, R.. 1997. Duden Abiturhilfen. Erzählende Prosatexteanalysieren, Training für Klausuren und Abitur (12. Und 13. Schuljahr). Mannheim: Duden Verlag.

Moleong, 2006. Metodologi Penelitian Kualitatif (Edisi Revisi). Bandung: Rosda Karya

Munaris. (2011). Resepsi Pembaca terhadap Unsur Fakta Cerita dalam Novel Ayat Ayat Cinta Karya Habiburrahman ElShyrazi. LITERA, 10(2), 171-182.

Nurgiyantoro, B. (2013). Teori Pengkajian Fiksi. Yogyakarta: Gadjah Mada University Press.
Nurgiyantoro, B. (2013). Sastra Anak Pengantar Pengembangan Dunia Anak. Yogyakarta: Gadjah Mada University Press.

Rogers, T. (2009). Interpreting ourselves and our worlds Literary Theory and Children's siterature : Interpreting Ourselves and Our Worlds. Theory Into Practice, 38(3), 138-146. https:// doi.org/10.1080/00405849909543845

Strehle, E. (1999). Social Issues : Connecting Children to Their World. Children's Literature in Education, 30(3), 213220.

Swandayani, D., Santoso, I., \& Nurhayati, A. (2013). Eropa Berdasarkan Tiga Novel Umberto Eco: Pembelajaran Sejarah Bagi Pembaca Indonesia. ATAVISME, 16(1), 27-41.

Thomas, J. (1986). Woods and Castles, Towers and Huts: Aspects of Setting in the Fairy Tale. Children's Literature in Education, 17(2), 126-134. 